\title{
The determination of physical activity, nutrition and self-sufficiency levels of sedanter individuals of fitness club member
}

\author{
Demirci N. ${ }^{1 \mathrm{ABCDE}}$, Toptaş Demirci P. ${ }^{2 \mathrm{ABCD}}$ \\ ${ }^{1}$ High School of Physical Education and Sport, Mersin University, Turkey \\ ${ }^{2}$ Erdemli Department of Tourism Animation, Mersin University, Turkey
}

Authors' Contribution: A - Study design; B - Data collection; C - Statistical analysis; D - Manuscript Preparation; E - Funds Collection.

\begin{tabular}{|c|c|}
\hline \multicolumn{2}{|l|}{ Abstract } \\
\hline Purpose: & $\begin{array}{l}\text { This study was planned to determine the physical activity (PA), nutrition and self-efficacy levels of sedentary } \\
\text { individuals have long been members of fitness clubs. }\end{array}$ \\
\hline Material: & $\begin{array}{l}\text { A total of } 80 \text { participants were divided into two groılps according to body mass index (BMI) according to } \\
\text { their obesity status: Group } 1 \text { (overvveight obesity (OW)) and Group } 2 \text { (Normal Weight (NW)). All participants } \\
\text { were watched for a year. The stıdy includes questionnaires on PA, eating habits, nutrition knovvledge and } \\
\text { self-efficacy. Descriptive statistics including frequency, percentiles, Inean and Standard deviation were used. } \\
\text { The T test was used to examine differences between PA, eating habits, nutrition knowledge and self-efficacy. } \\
\text { Statistical significance was accepted as } P<0.05 \text {. }\end{array}$ \\
\hline Results: & $\begin{array}{l}\text { Regarding participants' eating habits, the OW group was less frequent breakfast }(P<0.05) \text { and snack }(P<0.01) \text {, } \\
\text { ate more meals }(P<0.01) \text {. When coInpared with the NW group, they showed less desirable behavior during } \\
\text { the meal }(P<0.05 \text { for men). OW men spent less time }(P<0.01) \text { during vveekdays or weekends while doing } \\
\text { less PA }(P<0.01) \text {. OW woInen sat more in the vveekdays or weekends }(P<0.01) \text { and spent less time walking or } \\
\text { riding a bicycle }(P<0.05) \text { than the NW group. The nutritional information of the OW and NW groups was not } \\
\text { significantly different. Especially PA self-efficacy in OW was significantly lower than in NW group }(P<0.01) \text {. }\end{array}$ \\
\hline Conclusions: & $\begin{array}{l}\text { This study revealed differences betvveen PA, eating habits and self-efficacy betvveen OW and NW individuals. } \\
\text { Sedanter individuals who are members of fitness clubs should exercise exercise programs to prevent obesity } \\
\text { and to increase the confidence about exercise or physical activity. }\end{array}$ \\
\hline Keywords: & obesity, fitness club member, physical activity, nutrition information, self-sufficiency. \\
\hline
\end{tabular}

\section{Introduction}

Physical activity has a positive effect on the individual's both physical and functional capacity and health. When the benefits of physical activity are taken into account, optimal exercise provides individuals with healthier communities [1]. Research has shown that physical activity and exercise are essential for health [2-5]. The International Association of Health, Racquet and Sports Club estimates that 151 million people exercise in 187,000 sports and fitness centers worldwide [6]. Exercising in a fitness room exhibits three different forms of behavior on the individual: participation behaviors (when a person enters facility), continuation (an individual participates in a particular program), and eventual exercise (individual time, intensity, true) [7]. Participation in fitness clubs and research on exercise behavior are limited [8], but preliminary studies have identified low exercise sessions in sports clubs with an average of 1.1 sessions per month over a 24 -month period. Only $25 \%$ of the 259,000 old members were regularly exercised for six months in the $10 \%$ and $2.3 \%$ did not stop in two years [9]. These frequencies will not affect health well $[2,3]$.

Self-sufficiency is the belief in one's ability to overcome personal, social, and environmental barriers. There are two important aspects that will influence confidence in adopting and maintaining exercise behavior. The first is activity expectations; belief about their competencies. Second, beyond expectations; beliefs

(c) Demirci N., Toptaş Demirci P., 2018

doi:10.15561/18189172.2018.0503 about the results of one's own practice or the results of exercises. According to the self-efficacy theory, human behaviors are strongly influenced by self-regulation, for example, by self-regulation of exercise activities and selfdeterminative exercise goals [10]. Higher (perceived) self-efficacy further increases the likelihood that the individual will initiate and maintain behavior. A practice habit, for example, makes a call to enter a specific habit to remain motionless. It is conceptually related to selfsufficiency.

There is limited research on exercise behaviors of members of sports clubs [8]. According to [11], 46\% of women participate in cardio programs only and $51 \%$ of them participate in cardio and strength programs. $60 \%$ of men prefer to participate in strength training and cardio programs if only cardio is $33 \%$. In addition, while men $(60 \%)$ and women $(45 \%)$ were involved in group exercises, only $31 \%$ of women did not participate in group exercise programs. This participation is suggested to be a sign of exercise behavior. In a study of programa participation and exercise behavior in fitness clubs, [12], reported a $17 \%$ to $100 \%$ change in participation in programs. A study of members of the US sports clubs by DellaVigna and Malmendier [13] on attendance and attendance at the fitness club was conducted. A large number of 7.752 active members attendance have reported dropping from 5.46 to 4.32 in the first 6 months of to fitness clubs.

For this reason, it is very important to actively control obesity in individuals who are members of fitness clubs. Although the cause of obesity is complex, eating habits 
or lifestyle play an important role in the development of obese conditions $[14,15]$. Physical activity deficiency and malnutrition are accepted as an important risk factor. Physical activity may continue at any time of life [16, 17]. In particular, it is emphasized that as individuals age, they experience a significant decline in sedentary lifestyle and a significant decrease in their physical activity [18]. Physical inactivity is among the most important causes of the increase in the number of obese people. In addition, there is a close relationship between obesity and cardiovascular diseases, diabetes, osteoporosis, some types of cancer, mental problems and many health problems [19, 20]. Increased physical activity has a positive effect on obesity, and therefore, it is suggested that there are many studies that emphasize the effect of treatment with the preventive effect of the above mentioned diseases [21]. Factors related to eating or physical activity should also be identified to help sedentary individuals adopt healthy behaviors [22]. Knowledge of eating or physical activity is necessary to conduct the behavior, but it must be combined with these skills. Self-efficacy represents the ability to perform behavior and is known to be important in describing health behaviors such as eating and physical activity $[14,23]$. This study was designed to determine the physical activity (PA), nutrition and self-efficacy levels of sedentary individuals who have long been members of fitness clubs

\section{Material and Methods \\ Participants}

Before starting to work, necessary legal permissions were taken, the rules to be complied with were signed in detail, clarified to the individual, and an informed consent form. The study was conducted in accordance with the Helsinki declaration. The inclusion criteria are not a chronic disease, and the absence of chronic drug use means that there are no musculoskeletal problems that could affect physical activity. There is also a group of exercise programs already prepared to provide equal quality between the staff and group exercise programs that will carry out the group exercise sessions. This study was initiated by 129 sedanter individuals between 19-42 years of age. The study ended with a total of 80 participants, 35 female and 45 male, who were trying to improve their physical fitness levels in the ffitnes halls for a year. Body mass indexes (BMI) of 80 participants attending ffitness clubs at the end of the first 2 months were divided into two groups according to their obesity status: Group 1 (Overweight Obese (OW)) and Group 2 (Normal Overweight (NW)). At the end of the study, groups were asked about PA, eating habits, nutrition knowledge and self-efficacy.

Procedure

In this study, the same exercise programs were used for both groups. These programs were selected because they were prepared in advance and follow a standard format by the instructors. Exercise program sessions were planned as 3 days a week, 1 hour a day. Exercise programs include frequency and intensity of exercise as well as training $[24,25]$. The study questionnaire was based on sedanter individual' eating habits, physical activity and nutrition knowledge, and literature review to determine selfefficacy levels [26-28]. General features include the items of age, gender, height, weight, body mass index (BMI). The body mass index was calculated based on the weight and the dye reported. Participants' height measurements were measured by the millimetric height scale and body weight measurements by electronic scales. Body weight and height measurements were formulated by adding them to personal information forms. BMI = Body Weight $(\mathrm{kg}) /$ Boy2 (m). BMI values were obtained by dividing the body length by body weight after taking the length of the body length. Overweight-obese (OW) with BMI $\geq 25$ and BMI $18.5<\mathrm{BKI}<25$ were determined as those with normal weight (NW).

Data Collection Tools

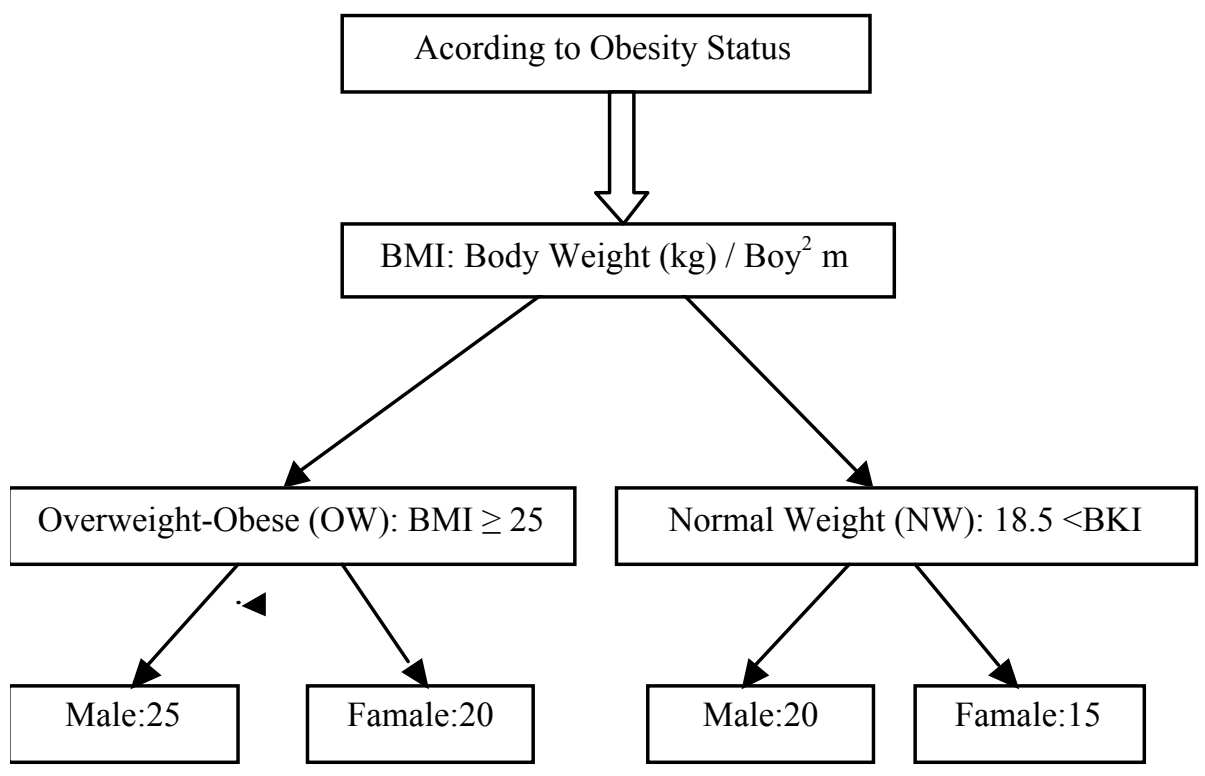

Figure 1. Participation in the study acording to obesity status 


\section{Eating Habits}

Eating habits included diverse foods, regular meals, size of food, frequency of breakfast meals, eating and snacks, behavior during meals, unbalanced diet and unfavorable food $[29,30]$. These variables were measured using 5-point scales or by asking them to record the frequency of their behavior or to check the categories.

Physical Activity

Physical activity is measured based on seven factors: the frequency of physical activity for at least 30 minutes per day, the frequency of walking or cycling, the frequency of exercise, weekday or weekend walking times, weekday or weekly moving time, by the number of activities they have performed $[31,32]$. The time spent walking was measured using four categories: "less than 30 minutes a day" or "more than 2 hours a day." The inactive time spent was measured using the categories "from less than one hour a day" to "no more than 4 hours a day".

Nutrition Knowledge

Nutrition knowledge was measured on 10 items, including general nutrition (six items) and information about obesity (four items) [29,30]. Information about obesity, definition of obesity, adequate weight control, fruit and energy and the effects of regular exercise. For each nutritional information item, the number and percentage of correct answers of the subjects were examined. The total score of the nutrition knowledge was the total score of the correct answers for 10 nutrition knowledge items.

Self-Efficacy

Self-efficacy obesity status in eating or physical activity was assessed using 10 items [27,30,33]. Selfefficacy in physical activity was measured using four items. They regularly participate in sports exercises, perceived efficacy on tired or bad weather conditions, driving at short distances, exercising at lunch or in the malls. Each item was measured on a 4-item scale between 'very difficult' (1) and 'very easy' (4). The total score for self-efficacy was calculated as a total of 10 item points.

Statistical Analysis.

SPSS (PASW Statistics 18.0; SPSS Inc., Chicago, IL, USA) was used for statistical analyses. Descriptive statistics including frequency, percentages, mean and standard deviation were calculated. Body weight and height measurements were formulated by adding them to personal information forms. BMI = Body Weight $(\mathrm{kg}) /$ Boy2 (m). BMI values were obtained by dividing the body length by body length after taking the body length. In this study T-test was used for parametric variables to examine the differences between the eating habits, physical activity, nutrition knowledge and self-efficacy according to obesity status. Chi-square analyses were conducted for non-parametric variables. Statistical significance was examined at $\mathrm{P}<0.05$.

\section{Results}

Sedanter Individuals Who Are Members of Fitness Clubs were found to be included in the age group $26.3 \pm$ 6.5 Normal Weight (NW) and 28.1 \pm 7.6 in the Overweight $\&$ Obesity (OW) group. The groups were significantly different according to their obesity status; OW group weight and BMI was higher than NW group while the height length was found to be lower $(\mathrm{P}<0.01)$ (Table 1).

The frequency of breakfast with sedentary individuals who were members of Fitnis clubs was average in male OW group (5.6 \pm 1.4$)$ and female OW group (5.7 \pm 1.6$)$. OW group values were higher than NW group men and women $(\mathrm{P}<0.05)$. while the frequency of eating outside did not vary among men OW women ate more food than NW women $(\mathrm{P}<0.01)$. The average snack frequency from both sexes was significantly higher in the OW group in males and females $((1.6 \pm 1.3) ;(1.6 \pm 1.2)$. In the NW group men and women, the average frequency of snacks was $1.2 \pm 0.8$ times daily, OW group $(1.6 \pm 1.3)$ per day in men and $(1.6 \pm 1.2)$ in women $(\mathrm{P}<0.01)$. OW reported that about $12 \%$ of men did not eat a wide variety of foods, and $28 \%$ said that a wide variety of foods were eaten too often. Approximately $10 \%$ of OW women reported that they did not eat a wide variety of foods, and $30 \%$ reported that a wide variety of foods were eaten too often. Approximately $20 \%$ of OW men and $35 \%$ of women were fed with very irregular food, while the rate of regular eating was $28.7 \%$ in total participants. The proportion of respondents who responded as 'small' or 'very small' according to the size of the food ratio was $48 \%$ in the OW group male, $55 \%$ in the OW group women ( $\mathrm{P}<0.001)$. Participants were observed to exhibit similar behaviors in

Table 1. General Descriptive Characteristics of Sedanter Individuals Who Are Members of Fitness Clubs

\begin{tabular}{llll}
\hline $\begin{array}{l}\text { Obesity Status } \\
\text { Variables }\end{array}$ & $\begin{array}{l}\text { Normal } \\
(\mathbf{n}=\mathbf{3 5})\end{array}$ & $\begin{array}{l}\text { Overweight \& Obesity } \\
(\mathbf{n}=\mathbf{4 5})\end{array}$ & $\begin{array}{l}\text { Total } \\
(\mathbf{n}=\mathbf{8 0})\end{array}$ \\
\hline Age & $26.3 \pm 6.5$ & $28.1 \pm 7.6^{2)}$ & $27.2 \pm 7.05$ \\
Weight $(\mathrm{kg})$ & $66.4 \pm 14.8$ & $77,2 \pm 11.6^{* *}$ & $71.8 \pm 13.2$ \\
Height $(\mathrm{cm})$ & $179,1 \pm 8.72$ & $168,8 \pm 6.65^{* *}$ & $173,9 \pm 7.68$ \\
BMI & $22.6 \pm 4.1$ & $28.2 \pm 3.4^{* *}$ & $25.4 \pm 3.7$ \\
Male & $20(44.5)$ & $25(55.5)$ & $45(100.0)$ \\
Famale & $15(42.8)$ & $20(57.2)^{3)}$ & $35(100.0)$ \\
\hline
\end{tabular}

* $\mathrm{P}<0.05, * * \mathrm{P}<0.01 ; 1) \mathrm{BKI} \geq 25$ overweight - obesity (OW) ve BKi $18.5<\mathrm{BKI}<25$ normal weight (NW); 2) Mean $\pm \mathrm{SD}$; 3) $\mathrm{n}(\%)$. 
eating. Approximately $68 \%$ of men in OW group and $75 \%$ of OW women were fed an unbalanced diet $(\mathrm{P}<0.001)$ (Table 2). No significant difference was observed between the participants regarding the unfavorable foods (Table 2).

It was found that $24 \%$ of men in the OW group and $40 \%$ of the women in the OW group did not do any physical activity at least 30 minutes per day during the week. OW group reported that $40 \%$ of men and $35 \%$ of women walked no day or did not ride bicycles. $40 \%$ of men in NW group and $46.8 \%$ of women walked at least $1-2$ days per week $(\mathrm{P}<0.05)$. During weekday OW group found that $36 \%$ of men and $40 \%$ of women and during the weekend $32 \%$ of OW group men and $50 \%$ of women were walking less than 30 minutes a day $(\mathrm{P}<0.05)(\mathrm{P}<0.01)$. OW and NW group men and women were on weekdays and weekend time spent during was between 30 minutes and 1 hour. The ratio of male and female OW group who had less physical activity on weekdays and weekends than three hours was higher than NW group (Table 3). Approximately $40 \%$ of women in the OW group never participated in physical activity in a week. The proportion of OW women exercising more than three hours a week $(10 \%)$ is lower than NW women. The rate of NW group men and OW group men exercising every other day was significantly similar (Table 3 ).

Table 2. Eating habits according to obesity status in Sedanter Individuals who are Members of Fitness Clubs

\begin{tabular}{|c|c|c|c|c|c|}
\hline \multirow[b]{2}{*}{ Variables } & \multicolumn{2}{|c|}{ Male (n=45) } & \multicolumn{2}{|c|}{ Famale (n=35) } & \multirow[b]{2}{*}{$\begin{array}{l}\text { Total } \\
(n=80)\end{array}$} \\
\hline & $\begin{array}{l}\text { Normal } \\
(n=20)\end{array}$ & $\begin{array}{l}\text { Overweight \& } \\
\text { Obesity } \\
(\mathrm{n}=25)\end{array}$ & $\begin{array}{l}\text { Normal } \\
(n=15)\end{array}$ & $\begin{array}{l}\text { Overweight } \& \\
\text { Obesity } \\
(\mathrm{n}=20)\end{array}$ & \\
\hline $\begin{array}{l}\text { Breakfast frequency (times/ } \\
\text { week) }\end{array}$ & $4.5 \pm 1.6$ & $5.6 \pm 1.4^{3)^{*}}$ & $\begin{array}{l}4.4 \\
\pm 1.7\end{array}$ & $5.7 \pm 1.6^{*}$ & $5.0 \pm 1.6$ \\
\hline $\begin{array}{l}\text { Frequency of eating out (times/ } \\
\text { week) }\end{array}$ & $1.1 \pm 0.8$ & $1.3 \pm 1.1$ & $\begin{array}{l}1.1 \pm \\
0.8\end{array}$ & $1.4 \pm 0.7^{* *}$ & $1.2 \pm 0.8$ \\
\hline $\begin{array}{l}\text { Frequency of eating snacks } \\
\text { (times/day) } \\
\text { Variety of foods }\end{array}$ & $1.2 \pm 0.8$ & $1.6 \pm 1.3^{* *}$ & $\begin{array}{l}1.2 \pm \\
0.8\end{array}$ & $1.6 \pm 1.2^{* *}$ & $1.4 \pm 1.0$ \\
\hline Do not eat a variety of foods at all & $2(10.0)$ & $3(12.0)^{4) *}$ & $1(6.7)$ & $2(10.0)^{*}$ & $8(10.0)$ \\
\hline Do not eat a variety of foods & $3(15.0)$ & $4(16.0)$ & $2(13.3)$ & $2(10.0)$ & $11(13.9)$ \\
\hline Average & $6(30.0)$ & $5(20.0)$ & $6(40.0)$ & $5(25.0)$ & $22(27.4)$ \\
\hline Eat a variety of foods & $6(30.0)$ & $6(24.0)$ & $4(26.7)$ & $5(25.0)$ & $21(26.2)$ \\
\hline $\begin{array}{l}\text { Eat a variety of foods very } \\
\text { often } \\
\text { Regular meals }\end{array}$ & $3(15.0)$ & $7(28.0)^{*}$ & $2(13.3)$ & $6(30.0)^{*}$ & $18(22.5)$ \\
\hline Very irregular & $1(5.0)$ & $6(24.0)$ & $1(6.7)$ & $7(35.0)^{* *}$ & $15(18.7)$ \\
\hline Irregular & $3(15.0)$ & $7(28.0)^{* *}$ & $2(13.3)$ & $4(20.0)$ & $16(20.0)$ \\
\hline Neither irregular nor regular & $5(25.0)$ & $4(16.0)$ & $3(20.0)$ & $3(15.0)$ & $15(18.7)$ \\
\hline Regular & $8(40.0)$ & $5(20.0)$ & $6(40.0)$ & $4(20.0)$ & $23(28.7)$ \\
\hline $\begin{array}{l}\text { Very regular } \\
\text { Size of meals }\end{array}$ & $3(15.0)$ & $3(12.0)$ & $3(20.0)$ & $2(10.0)$ & $11(13.9)$ \\
\hline Very small/ small & $6(30.0)$ & $12(48.0)^{* *}$ & $5(33.3)$ & $11(55.0)^{* *}$ & $34(42.5)$ \\
\hline Adequate & $8(40.0)$ & $8(32.0)$ & $7(46.7)$ & $5(25.0)$ & $28(35.0)$ \\
\hline Large/very large & $6(30.0)$ & $5(20.0)$ & $3(20.0)$ & $4(20.0)$ & $18(22.5)$ \\
\hline Behavior during meals & & & & & \\
\hline Just eating & $5(25.0)$ & $8(32.0)$ & $4(26.7)$ & $7(35.0)$ & $24(30.0)$ \\
\hline $\begin{array}{l}\text { Conversation with family } \\
\text { members }\end{array}$ & $5(25.0)$ & $6(24.0)$ & $5(33.3)$ & $6(30.0)$ & $22(27.4)$ \\
\hline Playing games or watching TV & $6(30.0)$ & $6(24.0)$ & $3(20.0)$ & $4(20.0)$ & $19(23.9)$ \\
\hline $\begin{array}{l}\text { Reading a book or others } \\
\text { Unbalanced diet }\end{array}$ & $4(20.0)$ & $5(20.0)$ & $3(20.0)$ & $3(15.0)$ & 15(18.7) \\
\hline Yes & $6(30.0)$ & $17(68.0)^{*}$ & $5(33.3)$ & $15(75.0)^{* *}$ & $43(53.7)$ \\
\hline No & $\begin{array}{l}14 \\
(70.0)\end{array}$ & $8(32.0)$ & $\begin{array}{l}10 \\
(66.7)\end{array}$ & $5(25.0)$ & $37(46.3)$ \\
\hline $\begin{array}{l}\text { Foods that they dislike } \\
\text { Grains and starches }\end{array}$ & & & & & \\
\hline Grains and starches & $1(5.0)^{5)}$ & $3(12.0)$ & $1(6.7)$ & $1(5.0)$ & $6(21.4)$ \\
\hline $\begin{array}{l}\text { Meat } \\
\text { Fish }\end{array}$ & $2(10.0)$ & $3(12.0)$ & $2(13.3)$ & $2(10.0)$ & $9(13.2)$ \\
\hline Fish & $3(15.0)$ & $2(8.0)$ & $3(20.0)$ & $2(10.0)$ & $10(6.3)$ \\
\hline Eggs & $3(15.0)$ & $2(8.0)$ & $2(13.3)$ & $3(15.0)$ & $10(9.5)$ \\
\hline Beans & $1(5.0)$ & $3(12.0)$ & $1(6.7)$ & $3(15.0)$ & $8(15.5)$ \\
\hline Vegetables & $2(10.0)$ & $2(8.0)$ & $2(13.3)$ & $3(15.0)$ & $9(10.0$ \\
\hline Fruits & $3(15.0)$ & $3(12.0)$ & $2(13.3)$ & $3(15.0)$ & $11(8.6)$ \\
\hline Dairy products & $2(10.0)$ & $3(12.0)$ & $1(6.7)$ & $2(10.0)$ & $8(6.9)$ \\
\hline Seaweeds ${ }^{2}$ & $3(15.0)$ & $4(16.0)$ & $1(6.7)$ & $1(5.0)$ & $9(8.6)$ \\
\hline
\end{tabular}

$* \mathrm{P}<0.05, * * \mathrm{P}<0.01 ; 1)$ Multiple answers; 2) Shellfish, soy bean paste, greasy foods, spicy foods, etc.; 3) Mean \pm SD; 4) $n(\%)$; 5) The number in parentheses is the percentage of total subjects in each group. 
Table 3: The level of physical activity according to obesity status of Sedanter Individuals who are Members of Fitness Clubs

\begin{tabular}{|c|c|c|c|c|c|}
\hline \multirow[b]{2}{*}{ Variables } & \multicolumn{2}{|c|}{ Male $(n=45)$} & \multicolumn{3}{|c|}{ Famale $(n=35)$} \\
\hline & $\begin{array}{l}\text { Normal } \\
(n=20)\end{array}$ & $\begin{array}{l}\text { Overweight \& } \\
\text { Obesity } \\
(\mathrm{n}=25)\end{array}$ & $\begin{array}{l}\text { Normal } \\
(n=15)\end{array}$ & $\begin{array}{l}\text { Overweight \& } \\
\text { Obesity } \\
(\mathrm{n}=20)\end{array}$ & $\begin{array}{l}\text { Total } \\
(n=80)\end{array}$ \\
\hline \multicolumn{6}{|c|}{$\begin{array}{l}\text { At least } 30 \text { minutes of physical activity } \\
\text { per day (days/week) }\end{array}$} \\
\hline No & $3(15.0)$ & $6(24.0)^{1 *}$ & $1(6.6)$ & $8(40.0)^{* *}$ & $18(22.5)$ \\
\hline $1-2$ & $8(40.0)$ & $8(32.0)$ & $6(40.0)$ & $6(30.0)$ & $28(35.0)$ \\
\hline $3-4$ & $5(25.0)$ & $5(20.0)$ & $4(26.8)$ & $3(15.0)$ & $17(21.3)$ \\
\hline $5-6$ & $3(15.0)$ & $4(16.0)$ & $3(20.0)$ & $2(10.0)$ & $12(15.0)$ \\
\hline 7 & 1(5) & $2(8.0)$ & $1(6.6)$ & $1(5.0)$ & $5(6.2)$ \\
\hline \multicolumn{6}{|c|}{ Walking or riding a bicycle (days/week) } \\
\hline No & $3(15.0)$ & $10(40.0)^{*}$ & $2(13.3)$ & $7(35.0)^{*}$ & $22(27.5)$ \\
\hline $1-2$ & $8(40.0)^{*}$ & $4(16.0)$ & $7(46.8)^{*}$ & $5(25.0)$ & $24(30.0)$ \\
\hline $3-4$ & $5(25.0)$ & $5(20.0)$ & $3(20.0)$ & $4(20.0)$ & $17(21.3)$ \\
\hline $5-6$ & $3(15.0)$ & $4(16.0)$ & $2(13.3)$ & $3(15.0)$ & $12(15.0)$ \\
\hline 7 & $1(5.0)$ & $2(8.0)$ & $1(6.6)$ & $1(5.0)$ & $5(6.2)$ \\
\hline \multicolumn{6}{|c|}{$\begin{array}{l}\text { Time spent walking during weekdays } \\
\text { (hours/day) }\end{array}$} \\
\hline$<30 \min$ & $4(20.0)$ & $9(36.0)^{*}$ & $3(20.0)$ & $8(40.0)^{* *}$ & $24(30.0)$ \\
\hline $30 \min \leq<1$ hour & $8(40.0)$ & $10(40.0)$ & $6(40.0)$ & $6(30.0)$ & $30(37.5)$ \\
\hline 1 hour $\leq<2$ hours & $5(25.0)$ & $4(16.0)$ & $4(26.7)$ & $4(20.0)$ & $17(21.3)$ \\
\hline 2 hours $\leq$ & $3(15.0)$ & $2(8.0)$ & $2(13.3)$ & $2(10.0)$ & $9(11.2)$ \\
\hline \multicolumn{6}{|c|}{$\begin{array}{l}\text { Time spent walking during the } \\
\text { weekend (hours/day) }\end{array}$} \\
\hline$<30 \mathrm{~min}$ & $3(15.0)$ & $8(32.0)^{\star}$ & $4(26.7)$ & $10(50.0)^{\star \star}$ & $25(31.3)$ \\
\hline $30 \min \leq<1$ hour & $9(45.0)$ & $10(40.0)$ & $6(40.0)$ & $6(30.0)$ & $31(38.7)$ \\
\hline 1 hour $\leq<2$ hours & $5(25.0)$ & $5(20.0)$ & $3(20.0)$ & $3(15.0)$ & $16(20.0)$ \\
\hline 2 hours $\leq$ & $3(15.0)$ & $2(8.0)$ & $2(13.3)$ & $1(5.0)$ & $8(10.0)$ \\
\hline \multicolumn{6}{|c|}{$\begin{array}{l}\text { Sedentary activity during weekdays } \\
\text { (hours/day) }\end{array}$} \\
\hline$<3$ & $12(60.0)$ & $16(64.0)^{\star *}$ & $7(46.8)$ & $13(65.0)^{\star *}$ & $48(60.0)$ \\
\hline $3 \leq$ & $8(40.0)$ & $9(36.0)$ & $8(53.2)$ & $7(35.0)$ & $32(40.0)$ \\
\hline \multicolumn{6}{|c|}{$\begin{array}{l}\text { Sedentary activity during the weekend } \\
\text { (hours/day) }\end{array}$} \\
\hline$<3$ & $11(55.0)$ & $18(72.0)^{\star *}$ & $7(46.8)$ & $14(70.0)^{\star *}$ & $50(62.5)$ \\
\hline $3 \leq$ & $9(45.0)$ & $7(28.0)$ & $8(53.2)$ & $6(30.0)$ & $30(37.5)$ \\
\hline \multicolumn{6}{|c|}{$\begin{array}{l}\text { Number of days for exercise (times/ } \\
\text { week) }\end{array}$} \\
\hline No & $2(10.0)$ & $5(20.0)$ & $2(13.3)$ & $8(40.0)^{\star *}$ & $17(21.3)$ \\
\hline 1 & $8(40.0)$ & $10(40.0)$ & $6(40.0)$ & $7(35.0)$ & $31(38.7)$ \\
\hline 2 & $6(30.0)$ & $6(24.0)$ & $4(26.7)$ & $3(15.0)$ & 19(23.7) \\
\hline $3 \leq$ & $4(20.0)$ & $4(16.0)$ & $3(20.0)$ & $2(10.0)$ & $13(16.3)$ \\
\hline
\end{tabular}

$* \mathrm{P}<0.05, * * \mathrm{P}<0.01 ; 1) \mathrm{n}(\%)$.

There was no significant difference between OW and NW groups in terms of general nutrition knowledge score, obesity knowledge score, and nutrition knowledge total score in both genders. Similarly, there was no significant difference in eating self-efficacy scores between OW and NW groups. OW groups men and women were found to have lower physical activity self-efficacy scores (P $<0.01)$. However, no significant difference was found in physical activity self-efficacy scores of male and female NW group. OW male and female physical activity selfefficacy scores were significantly lower than NW women $(\mathrm{P}<0.01)$. However, the $\mathrm{OW}$ group was found to be significant in the total self-efficacy score $(P<0.01)$ in women (Table 4).

\section{Discussion}

Nowadays industrialization and modern lifestyle reduce physical mobility, which in turn affects the individual in every age and brings serious health problems to the agenda. Physical inactivity, defined as the most insidious disease of our time, is a major public health problem

[34]. Research on different populations of physical activity and exercise (USA and Europe) has shown that less than $5 \%$ of adults exercise a minimum amount $[35,36]$. Moreover research has shown that $50 \%$ of those participating in exercise programs in the fitness centers split in the first six months [37]. This study was designed to determine the physical activity (PA), nutrition and selfefficacy levels of sedentary individuals who have long been members of fitness clubs. Sedanter Individuals Who Are Members of Fitness Clubs were found to be included in the age group $26.3 \pm 6.5$ Normal Weight (NW) and $28.1 \pm 7.6$ in the Overweight \& Obesity (OW) group. The groups were significantly different according to their obesity status; OW group weight and BMI was higher 
Table 4: Nutritional knowledge and self-efficacy levels according to obesity status in Sedanter Individuals who are Members of Fitness Clubs

\begin{tabular}{|c|c|c|c|c|c|}
\hline \multirow[b]{2}{*}{ Variables } & \multicolumn{2}{|c|}{ Male $(n=45)$} & \multicolumn{3}{|c|}{ Famale $(n=35)$} \\
\hline & $\begin{array}{l}\text { Normal } \\
(n=20)\end{array}$ & $\begin{array}{l}\text { Overweight \& } \\
\text { Obesity } \\
\text { (n=25) }\end{array}$ & $\begin{array}{l}\text { Normal } \\
(n=15)\end{array}$ & $\begin{array}{l}\text { Overweight \& } \\
\text { Obesity } \\
(\mathrm{n}=20)\end{array}$ & $\begin{array}{l}\text { Total } \\
(n=80)\end{array}$ \\
\hline \multicolumn{6}{|l|}{ Nutrition Knowledge } \\
\hline $\begin{array}{l}\text { General nutrition knowledge } \\
\text { score }^{1)}\end{array}$ & $4.1 \pm 0.6$ & $3.6 \pm 0.5$ & $4.2 \pm 0.7$ & $3.6 \pm 0.5$ & $3.8 \pm 0.6$ \\
\hline Obesity knowledge score & $3.3 \pm 0.7$ & $3.1 \pm 0.6$ & $3.2 \pm 0.6$ & $3.0 \pm 0.6$ & $3.1 \pm 0.6$ \\
\hline $\begin{array}{l}\text { Nutrition knowledge total } \\
\text { score } \\
\text { Self-efficacy }\end{array}$ & $7.6 \pm 1.3$ & $7,7 \pm 1.1$ & $7.8 \pm 1.4$ & $7.7 \pm 1.1$ & $7.7 \pm 1.2$ \\
\hline Eating self-efficacy score & $18.1 \pm 2.7$ & $18.2 \pm 2.6$ & $18.5 \pm 3.0$ & $19.0 \pm 3.1$ & $18.4 \pm 2.8$ \\
\hline $\begin{array}{l}\text { Physical activity self-efficacy } \\
\text { score }\end{array}$ & $13.2 \pm 2.1$ & $11.3 \pm 2.6^{* *}$ & $13.1 \pm 2.3$ & $11.2 \pm 2.6^{* *}$ & $12.2 \pm 2.4$ \\
\hline Self-efficacy total score & $32.4 \pm 4.2$ & $31.9 \pm 4.1$ & $31.8 \pm 4.1$ & $30.7 \pm 3.7 * *$ & $31.7 \pm 4.0$ \\
\hline
\end{tabular}

Mean $\pm S D,{ }^{* *} P<0.01$

than NW group while the height length was found to be lower.

According to our research results; the frequency of breakfast with sedentary individuals who were members of Fitnis clubs OW group values were higher than NW group men and women. While the frequency of eating outside did not vary among men OW women ate more food than NW women. The average snack frequency from both sexes was significantly higher in the OW group in males and females. OW reported that about $12 \%$ of men did not eat a wide variety of foods, and $28 \%$ said that a wide variety of foods were eaten too often. Approximately $10 \%$ of OW women reported that they did not eat a wide variety of foods, and $30 \%$ reported that a wide variety of foods were eaten too often. Approximately $20 \%$ of OW men and $35 \%$ of women were fed with very irregular food, while the rate of regular eating was $28.7 \%$ in total participants. The proportion of respondents who responded as 'small' or 'very small' according to the size of the food ratio was $48 \%$ in the OW group male, $55 \%$ in the OW group women $68 \%$ of men in OW group and $75 \%$ of OW women were fed an unbalanced diet. No significant difference was observed between the participants regarding the unfavorable foods. In a study [38], it was found that the proportion of individuals with regular eating patterns in young Japanese was low. Skipping breakfast is associated with low nutritional status and the risk of cardiovascular disease. It has been reported that inadequate breakfast habits may contribute to the development and further development of obesity [29]. According to many research results; suggest that eating habits, eating disorder, unbalanced diet, and sedentary lifestyle may lead to overweight and obesity [28,40,41].

This study revealed that $24 \%$ of men in the OW group and $40 \%$ of the women in the OW group did not do any physical activity at least 30 minutes per day during the week. OW group reported that $40 \%$ of men and $35 \%$ of women walked no day or did not ride bicycles. $40 \%$ of men in NW group and $46.8 \%$ of women walked at least
1-2 days per week. During weekday OW group found that $36 \%$ of men and $40 \%$ of women and during the weekend $32 \%$ of OW group men and $50 \%$ of women were walking less than 30 minutes a day. OW and NW group men and women were on weekdays and weekend time spent during was between 30 minutes and 1 hour. The ratio of male and female OW group who had less physical activity on weekdays and weekends than three hours was higher than NW group. Approximately $40 \%$ of women in the OW group never participated in physical activity in a week. The proportion of OW women exercising more than three hours a week $(10 \%)$ is lower than NW women. The rate of NW group men and OW group men exercising every other day was significantly similar. There is a consensus on whether regular and appropriate physical activity and lifelong exercise can have a great positive impact on health and well-being $[42,43]$. The current recommendation of the World Health Organization [44] states that adults should collect physical activity for at least 150 minutes per week for at least 10 weeks at medium intensity (or at least 75 minutes for intense intensity). In addition, it is recommended that children and adolescents have moderate physical activity for at least 60 minutes each day [44]. However, despite these recommendations and the adverse effect of inactivity, the data on study indicate that the vast majority of participants did not achieve the recommended daily and weekly physical activity levels. Physical inactivity is among the most important causes of the increase in the number of obese people. In addition, there is a close relationship between obesity and cardiovascular diseases, diabetes, osteoporosis, some types of cancer, mental problems, and many health problems in studies conducted $[19,20]$. Increasing physical activity has a positive effect on obesity, and therefore it is suggested that there are many studies emphasizing the effect of treatment with the preventive effect on the above mentioned diseases [21].

This study shows that; There was no significant difference between $\mathrm{OW}$ and NW groups in terms of 
general nutrition knowledge score, obesity knowledge score, and nutrition knowledge total score in both genders. OW male and female physical activity selfefficacy scores were significantly lower than NW women. However, the OW group was found to be significant in the total self-efficacy score in women. Middelkamp et al. [7] reported that only $18 \%$ of the members of the fitness clubs continued to exercise. The effects on fitness behaviors of fitness coaches have been suggested to be terminated quickly after the end of the program, even when the coaching protocol stimulates significantly more participants to continue exercising in the same fitness clubs. This indicates that the exercise behaviors of the members of the fitness clubs are gradually declining and the exercise fit is very weak. Other studies that performed similar self-efficacy based interventions with significant results did not test the long term effects of the fitness program after the end of the program $[45,46]$. Contrary to our expectation, perceived confidence in eating behavior was not significantly different from obesity in was no significant difference between OW and NW groups. This was finding unlike a previous study of self-efficacy for nutritional behavior.

As a result, it was determined that regarding participants' eating habits, the OW group was less frequent breakfast and snack, ate more meals. When coinpared with the NW group, they showed less desirable behavior during the meal for men). OW men spent less time during vveekdays or weekends while doing less PA. OW woinen sat more in the vveekdays or weekends and spent less time walking or riding a bicycle than the NW group. The nutritional information of the OW and NW groups was not significantly different. Especially PA self-efficacy in OW was significantly lower than in NW group. Sedanter individuals are at risk due to lack of nutrition information, TV and peer interaction and so on. Sedanter members who are members of fitness clubs should exercise exercise programs to prevent obesity and to increase the confidence about exercise or physical activity.

\section{Conclusions}

Fitness exercise programs should focus on increasing obesity management programs, self-efficacy, changing eating habits, and increasing PA. In this context, fitness exercise programs should include adequate methods of body image, body satisfaction and weight control, and awareness should be created by conveying information to the related individuals. Conclusion: This study revealed differences betvveen PA, eating habits and self-efficacy betvveen OW and NW individuals. Sedanter individuals who are members of fitness clubs should exercise exercise programs to prevent obesity and to increase the confidence about exercise or physical activity.

\section{Conflicts of Interest}

There isn't any conflict of interest to be declared regarding the manuscript.

\section{References}

1. Miçooğulları O, Cengiz C, Aşçı H, Kirazcı S. Examinations of young adults' exercise self efficacy and decisional balance with regard to gender and exercise stage of change, Hacettepe J. of Sport Sciences, 2010; 21 (2): 49-59.

2. ACSM's guidelines for exercise testing and prescription. American College of Sports Medicine. 9th revised edition. Wil-liams \& Wilkins; 2014.

3. Dishman RK, Heath GW, Lee IM. Physical activity epidemiology. 2nd edition. Cham-paign, USA: Human Kinetics Publishers; 2013.

4. Lavie CJ, Johannsen N, Swift D, Sénéchal M, Earnest C, Church T, Hutber A, Sallis R, Blair SN. Exercise is Medicine: The Importance of physical activity, exercise train-ing, cardiorespiratory fitness, and obesity in the prevention and treatment of type 2-diabetes US. Endocrinology, 2013; 9(2):95-100

5. Ross R, Blair SN, Arena R, Church TS, Despr R JP, Franklin BA, Haskell WL, Kaminsky LA, Levine BD, Lavie CJ, Myers J, Niebauer J, Sallis R, Sawada SS, Sui X, Wisl SU. Importance of assessing cardiorespira-tory fitness in clinical practice: a case for fitness as a clini-cal vital sign. Circulation, 2016; 134(24): 653-699

6. Baart de la Faille M, Middelkamp J, Steenbergen J. The state of research in the global fitness industry. BlackBoxPublishers, Netherlands; 2012.

7. Middelkamp J, Van Rooijen M, Steenbergen B. Attend-ance behavior of ex-members in fitness clubs: A retrospective study applying the stages of change. Perceptual and Motor Skills, 2016; 122(1): 350-359.

8. Middelkamp J, Steenbergen B. The transtheoretical model and exercise behaviour of members in fitness clubs: systematic review. Journal of Fitness Research, 2015; 4: 43-54.

9. Middelkamp J, Rooijen MV, Wolfhagen P, Steenbergen B. The effects of a self-efficacy intervention on exercise behavior of fitness club members in 52 weeks and long-term relationships of transtheoretical model constructs. Journal of Sports Science and Medicine, 2017; (16): 163-171.

10.Bandura A. Self-efficacy: The exercise of control. New York: Freeman; 1997.

11.Hover P, Hakkers S, Breedveld K. Trendrapport fitnessbranche 2012. Mulier Instituut, Den Bosch \& Arko Sportsmedia, Nieuwegein; 2012.

12.Annesi JJ, Mazas J. Effects of virtual reality-enhanced exercise equipment on adherence and exercise-induced feeling states. Perceptual and Motor Skills, 1997; 85: 835844.

13.DellaVigna S, Malmendier U. Paying not to go to the gym. The American economic review, 2006; 96: 604-719.

14.Hatfield DP, Chomitz VR, Chui KK, Sacheck JM, Economos CD. Demographic, physiologic, and psychosocial correlates of physical activity in structured exercise and sports among low-income, overweight children. J Nutr Educ Behav, 2015; 47:452-458

15.Lee SY, Ha SA, Seo JS, Sohn CM, Park HR, Kim KW. Eating habits and eating behaviors by family dinner frequency in the lower-grade elementary school students. Nutr Res Pract, 2014; 8:679-87.

16.Brown JE, Isaacs JS, Krinke UB, Lechtenberg E, Murtaugh MA, Sharbaugh C, Splett PL, Stang J, Wooldridge NH. Nutrition through the life cycle. 4th ed. Belmont (CA): Wadsworth; 2011. 
17.Malina RM. Adherence to physical activity from childhood to adulthood: a perspective from tracking studies". Quest, 2011; 53:346-355.

18.Leslie E, Fotheringham MJ, Owen N, Bauman A. Age related differences in physical activity level of young adults. Medicine and Science in Sports and Exercise, 2001; (33): 255-258, 2001.

19.Kimber C, Abercrombie E, Epping JN, Mordecai L, Newkirk J Jr, Ray M. Elevating physical activity as a public health priority: establishing core competencies for physical activity practitioners in public health. Journal of Physical Activity and Health, 2009; 6(6):677-81.

20.Kohl HW, Lee IM, Vuori IM, Wheeler FC, Bauman A, Sallis JF. Physical Activity and Public Health: the Emergence of a Sub Discipline. Journal of Physical Activity and Health, 2006; (3): 344- 364.

21.Ryan E. Rhodes, Ian Janssen, Shannon S.D. Bredin, Darren E.R. Warburtonc and adrian bauman. physical activity: Health impact, prevalence, correlates and interventions. Psychology \& Health, 2017; 32(8): 942-975.

22.Nayera E. Hassan, Saneya A. Wahba, Sahar A. El-Masry, Enas R. Abd Elhamid, Samia A.W. Boseila, Nihad H. Eating Habits and Lifestyles among a Sample of Obese Working Egyptian Women, Open Access Macedonian Journal of Medical Sciences, 2015; 15; 3(1):12-17.

23.Keihner AJ, Meigs R, Sugerman S, Backman D, Garbolino T, Mitchell P. The power play! Campaign's school idea \& resource kits improve determinants of fruit and vegetable intake and physical activity among fourth- and fifth-grade children. J Nutr Educ Behav, 2011; 43: S122-9.

24.Harvey A. Quantifying and comparing activity in group exercise classes: A literature review. Journal of Fitness Research, 2012; 1: 50-65.

25.Khan RS, Marlow C, Head A. Physiological and psychological responses to a 12-week Bodybalance training programme. Journal of Science and Medicine in Sport, 2008; 11:299-307.

26. Cho YG, Song HR, Kim KA, Kang JH, Song YH, Yun HJ, Kim HS. Effect of a school-based intervention for overweight children "fitness class" performed on elementary schools located in Seoul. Korean J Obes, 2009;18:146-57.

27.Kang JH. Relationship between physical activity and psychological factors in obese children [doctor's thesis]. Seoul: Korea National Sport University; 2009.

28.Seong AH, Lee SY, Kim KA, Seo JS, Sohn CM, Park HR, Kim KW. Eating habits, physical activity, nutrition knowledge, and self-efficacy by obesity status in uppergrade elementary school students. Nutrition Research and Practice, 2016;10(6):597-605.

29.Choi HJ, Seo JS. Nutrient intakes and obesity-related factors of obese children and the effect of nutrition education program. Korean J Community Nutr, 2003;8:477-84.

30.Na SY, Ko SY, Eom SH, Kim KW. Intakes and beliefs of vegetables and fruits, self-efficacy, nutrition knowledge, eating behavior of elementary school students in Kyunggi area. Korean J Community Nutr, 2010;15:329-41.
31.Centers for Disease Control and Prevention (US). State and Local Youth Risk Behavior Survey. Clifton road Atlanta (GA): Centers for Disease Control and Prevention; 2007.

32. Guthold R, Cowan MJ, Autenrieth CS, Kann L, Riley LM. Physical activity and sedentary behavior among schoolchildren: a 34-country comparison. $J$ Pediatr, 2010;157:43-49.

33.Ko SY, Kim KW. Nutrition label use, self-efficacy, snacking and eating behavior of middle school students in Kyunggi area. Korean J Community Nutr, 2010;15:513-24.

34.Soyuer F, Soyuer A. Older adults and physical activity. İn̈nü University Journal of Medical Faculty, 2008; 15(3): 219-24.

35.Cavill N, Kahlmeier S, Racioppi F. Physical activity and health in Europe: Evidence for action. Copenhagen, Denmark: World Health Organization; 2006.

36. Garber CE, Blissmer B, Deschenes MR, Franklin BA, Lamonte MJ, Lee IM, Nieman DC, Swain DP. Quantity and quality of exercise for developing and maintaining cardi-orespiratory, musculoskeletal, and neuromotor fitness in appar-ently healthy adults: Guidance for prescribing exercise. Medicine \& Science in Sports \& Exercise, 2011; 43:1334-1359.

37.Berger BG, Pargman D, Weinberg RS. Foundations of exercise psychology. Morgantown, WV: Fitness Information Technology; 2002.

38.Sakata K, Matumura Y, Yoshimura N. Relationship between skipping breakfast and cardiovascular disease risk factors in the national nutrition survey data. Nippon Koshu Eisei Zasshi, 2001; 48: 837-41.

39. Ortega RM, Redondo MR, Lopez-Sobaler AM. Associations between obesity, breakfast-time food habits and intake of energy and nutrients in a group of elderly Madrid residents. $J$ Am Coll Nutr, 1996; 15: 65-72.

40.Lobstein T, Baur L, Uauy R. IASO International Obesity TaskForce. Obesity in children and young people: a crisis in public health. Obes Rev, 2004;5 (Suppl 1):4-104.

41.Baek S. Do obese children exhibit distinguishable behaviours from normal weight children? - based on literature review. Korean J Community Nutr, 2008;13:386-95.

42.Blair SN. Physical inactivity: The biggest public health problem of the 21 st century. British Journal of Sports Medicine, 2009; 43(1): 1-2.

43.Trost SG, Blair SN, Khan KM. Physical inactivity remains the greatest public health problem of the 21st century: Evidence, improved methods and solutions using the ' 7 investments that work' as a framework. British Journal of Sports Medicine, 2014; 48: 169-170. doi:10.1136/bjsports2013-093372

44. World Health Organization (WHO). Global recommendations on physical activity for health. Geneva: Switzerland; 2010.

45.Seghers J, Van Hoecke AS, Schotte A, Opdenacker J, Boen F. The added value of a brief self-efficacy coaching on the effectiveness of a 12-week physical activity program. Journal of Physical Activity and Health, 2014; 11(1): 18-29.

46.Annesi JJ. Goal-setting protocol in adherence to exercise by Italian adults. Perceptual and Motor Skills, 2002; 94: 453458 . 


\section{Information about the authors:}

Demirci N.; Dr.; http://orcid.org/0000-0001-8442-270X; nevzatdemirci44@hotmail.com; High School of Physical Education and Sports, Mersin University; Mersin, 33343, Turkey.

Toptaş Demirci P.' http://orcid.org/0000-0002-3745-8440; pervindemirci36@hotmail.com; Erdemli Department of Tourism Animation, Mersin University; Mersin, 33343, Turkey.

Cite this article as: Demirci N, Toptaş Demirci P. The determination of physical activity, nutrition and self-sufficiency levels of sedanter individuals of fitness club member. Pedagogics, psychology, medical-biological problems of physical training and sports, 2018;22(5):237-245. doi:10.15561/18189172.2018.0503

The electronic version of this article is the complete one and can be found online at: http://www.sportpedagogy.org.ua/index.php/PPS/issue/archive

This is an Open Access article distributed under the terms of the Creative Commons Attribution License, which permits unrestricted use, distribution, and reproduction in any medium, provided the original work is properly cited (http://creativecommons.org/licenses/by/4.0/deed.en).

Received: 18.08 .2018

Accepted: 10.09.2018; Published: 30.09.2018 